\title{
PROCEDURE OF TEACHING GRAMMAR USING MEMORY ENHANCEMENT
}

\author{
Herri Susanto \\ Sekolah Tinggi Teknologi Bontang \\ Jl. Ir. H. Juanda No. 73, Bontang, East Kalimantan \\ herriaudrey@yahoo.com
}

\begin{abstract}
Teaching grammar has been regarded as a process of understanding from the context. It means a teacher teaches the pupils contextually more than just the rules. However, I have my own experience that teaching grammar methods must depend on the purposes of learning grammar. Some people learn grammar as a means to fulfill the syllabus needs for schools but other people learn grammar for special purposes out of school syllabus, such as for entrance test. For these reasons, the methods of teaching grammar should be different. The students who learn grammar based on the school syllabus probably needs longer procedure of learning that usually uses contextual teaching through listening, speaking, writing, and reading. Nevertheless, students who learn grammar for test need shorter procedure of learning such as memorizing. Therefore, I propose giving a workshop of teaching grammar using memory enhancement as another alternative teaching grammar method. This workshop would show the class that grammar can be learnt through memory enhancement process, i.e.; mind map, music, memory technique and drill to boost up students understanding for test preparation.
\end{abstract}

Keywords: teaching grammar, teaching procedure, memory enhancement

\begin{abstract}
ABSTRAK
Pengajaran tata bahasa dianggap sebagai proses pemahaman konteks. Artinya seorang guru mengajarkan siswa lebih secara kontekstual dari pada sekedar aturan. Namun, berdasarkan pengalaman saya sendiri bahwa metode pengajaran tata bahasa bergantung pada tujuan pembelajarannya. Beberapa orang belajar tata bahasa sebagai sarana untuk memenuhi kebutuhan silabus sekolah sementara orang lain belajar untuk tujuan khusus seperti ujian masuk. Untuk alasan ini, metode pengajaran tata bahasa harus berbeda. Para siswa yang belajar tata bahasa berdasarkan silabus sekolah mungkin perlu prosedur belajar yang lebih lama yang biasanya menggunakan pembelajaran kontekstual melalui pelajaran mendengarkan, berbicara, menulis, dan membaca. Namun demikian, siswa yang belajar tata bahasa untuk ujian perlu prosedur belajar yang lebih singkat seperti menghafal. Oleh karena itu, saya mengusulkan untuk memberikan lokakarya pengajaran tata bahasa dengan peningkatan memori sebagai metode pengajaran alternatif. Workshop ini akan menunjukkan bahwa tata bahasa dapat dipelajari melalui proses memori perangkat tambahan, yaitu; peta pemikiran, musik, teknik dan latihan memori untuk meningkatkan pemahaman siswa untuk persiapan ujian.
\end{abstract}

Kata kunci: pengajaran tata bahasa, prosedur pengajaran, peningkatan memori 


\section{INTRODUCTION}

Teaching grammar is very important in language teaching, whether it is presented for teaching English as Second Language (ESL) or even for teaching English as a Foreign Language (EFL). Both presentations purposes; therefore, need appropriate approaches to apply. When students' goal is linguistics competence, then they tend to learn grammar using broadly speaking, in teaching grammar, there are two approaches that can be applied: deductive and inductive (Thornburry, 1999). Thornburry (1999, p.29) defines that a deductive approach starts with the presentation of rule and is followed by examples in which the rule is applied, while inductive approach starts the explanation with some examples from which a rule is inferred.

Based on my experience of teaching grammar for test takers, the appropriate approach used is deductive approach. Through the deductive approach, a teacher tries to teach the rule explicitly to the learners so that they are ready to cope with exercises given. Having given the explicit rule, the learners become more confidence in doing certain tasks. To be successful in applying the approach, the teacher needs to provide numerous exercises. In other words, teaching deductively works from the general into the specific.

In this paper, I would like to stress that there are four important points to discuss. The points are target of learners, teachers' role, memory enhancement technique and tools, and procedure of teaching which are connected one to another bounded in one package of teaching process.

\section{Target of Learners}

Teaching grammar is not as easy as it seems since there should have better treatment matched with the target of teaching. Thornburry (1999, p.27) explains there are ten factors to consider when determining appropriation. The factors include age, level, size of the group, constitution of the group whether monolingual or multilingual, the need, interest, materials and resources availability, cultural factors, and educational context whether the learners study at school or somewhere else. Here, age factor is one of the essential factors to consider forming a class setting. If one class has the same level, age, and the same goal, this eases the performance of teaching.

Moreover Thornburry (1999) adds stressing on the way of teaching grammar between different ages must be think about deeply. He tends to place adults to study grammar implicitly so they can learn through rules and examples. He says:

"The age of the learners is very important. Researchers suggest that children are more disposed to language learning activities that incline toward acquisition rather than toward learning... Adult learners, on the other hand, may do better at activities which involve analysis and memorization (27)”.

In short, adults can be taught grammar in more serious way such as giving memorization techniques and analyzing the grammar patterns than children. Besides, adults seem more ready to have memorizing techniques. Pressley \& Dennis-Rounds (1980) examined the use of mnemonics at two different age levels (middle school vs. high school students). The results showed that only the high school students were able to successfully transfer the memory strategy to other dissimilar information. Thus, adults once again are more appropriate to learn memorizing than children.

\section{Teacher's Role}

In line with the teaching approaches showed above, teacher's role is more dominant than the students. A teacher has a very important role in the teaching and learning process since the teacher is the model for the students to do activities in class and out of class. However, the role of the teacher 
sometimes is used only as a motivator, and facilitator. These two points of view underline two teaching methods brought in the classroom. Hence, the teaching methods can be grouped into two namely, pupil-centered and teacher-centered.

According to Alabi (2008, p.843) teacher-centered method puts teachers are the main actors while the pupils are passive listeners. The pupils remain silent the most of the time during the lesson. On the other hand, pupil-centered is the opposite of teacher-centered. Pupil-centered methods the teachers act as guide or adviser to the pupils, suggesting activities that are appropriate. The pupils are actively doing the study under the leadership of the teacher. In other words the teacher is the central of all activities to manage and to advise the learners in the teaching process.

Based on my experience, teacher-centered method can be applied for language competence in its learning process. Mostly, the teacher gives teaching presentation in front of the class and the learners listen and do exercise based on what the teacher instructs. For example when teachers should teach for test takers, like; TOEFL, TOEIC, and University Entrance Test, they should learn grammar by the guidance of their teachers. Since the stages of teaching focus on the teacher acts, teachercentered method is the most appropriate methods than learner-centered method in the classroom. Using teacher centered method means there will be no activity like role-play, discussion, and other activities required to communicate among the learners as a media to practice the materials given.

Having known the target of the students and teacher's role in applying deductive approach in the class to set the class readiness for teaching grammar, next, now I move to the core of discussion of memory techniques and procedure of teaching.

\section{Memory Technique}

Teaching students with memory enhancement mean teaching students use memory technique or link-word method (Joyce \& Weil, 2000) and also additional tools to improve the memory (This technique has been used for quite some time in the classrooms (Atkinson, 1975; Lorayne and Lucas, 1974, Rose, 1995; Jensen and Markowitz, 2003).

Atkinson and Pressley (as cited by Joyce \& Weil, 2000) summarize that memory techniques proved to be effective to help students to learn new materials. Even Atkinson's early studies observed that the memory techniques were about 50 percent more effective than conventional rote methods.

Memory Technique is also called as mnemonics. According to Tony Buzan (1986, P.16), he says "The memory technique or mnemonics were a system of memory codes that enable people to remember whatever it was they wished to remember". These techniques have been known for long time ago used to remember fact and to remember information. In the past people memorized some information using method of Loci. According to www.intelligen.inc.com, it states the definition of Loci method "The ancients remembered things by imagining taking a familiar walk, and placing the things to be remembered at locations along the way." This method works because it organizes the material to be remembered and it encourages elaborative processing and memorable imagery.

Therefore, Harry Lorayne (1995, P.20) says "Mnemonics, which is a large part of a trained memory, is not a new or strange thing". Besides, He adds that mnemonics is not a new or strange thing because it is true that the word "mnemonic" is derived from the name of the Greek Goddess, Mnemosyne; and a memory system was used as far back as early Greek civilization. Thus, mnemonic is something that assists on memory.

No wonder, if many ancient great people could remember a number of locations, names, etc without any mistake using this technique. For example, Lucius Scipio was able to remember the name 
of people of Rome, Cyrus was able to recall thousands soldiers of his army by name and Seneca could memorize and repeat two thousand words, after hearing them once.

Recently, many researchers have developed this techniques, such as Levin, Morrison, Mc Given, Mastropieri, \& Scruggs, 1986; Scruggs \& Mastropieri, 1992 (as quoted by Richmond et al, 2000). They believed that mnemonic instruction, a specific memory technique, as one of the more effective ways to improve eight-grade science knowledge.

In conclusion, the Greek orators (speakers) in the past up to students in the recent years would use this method to help them memorize. They used techniques of memorizing whether it is method of loci or mnemonic to remember names, dates, etc. Buzan (1984, p.63) also agrees with the need of using mnemonics since its function is to remember something more easily and quickly, and then to remember it too much longer afterwards, must be more than simple tricks.

\section{Memory Enhancement Tools}

Learners need tools to strengthen the memory because information is sometimes easy to remember and easy to forget. Having learned the memory technique or mnemonics there are three more additional strategies used that are also able to enhance memory. They are mind map, break time, and music. The following explanation will explore those three tools.

\section{Mind Map}

According to Tony Buzan (2007), a mind map is a diagram used to represent words, ideas, tasks, or other items linked to and arranged around a central key word or idea. Mind maps are used to generate, visualize, structure, and classify ideas, and as an aid in study, organization, problem solving, decision making, and writing. In other words, mind map is a creative and effective way to place whatever stated in mind which then is visualized into a diagram started with central key words on it.

Tony Buzan says that mind map is used to do many things in creative ways, this means that the processes of making mind map should relate to the function of brain sides; the left side and right side. The left brain represents the capability of stating words, numbers, and logic while the right brain represents the capability to for pictures, colors, and imaginations. Gannerud and Ronnerman (2005) also observed that the use of mind map creates a good interaction between researchers and teachers, and it allows teachers' own talk about their everyday work to become visualized in an effective and clear way (p. 79). Furthermore, mind map was successfully applied in many subjects at schools such as Mathematics, psychology, and language (Meier. 2007, Puskhar. and Brinkman. 2003). Next, Puskhar strongly underlined that the mindmaps enhance, above all, the student's ability to effectively store information, that is, to retain and comprehend it.

Tony Buzan (2007, p.122) observes that mind map is one of ways to ease the learners to arise imagination and memory. Buzan is quite agreeing that mind map rules an important role besides other ways to memorize some important information. In order to memorize words and vocabulary, everybody may use mind map since there are rules to make the mind map succeed helping the maker. There are association, imagination, ideas, colors, lines and symbols inside it. Furthermore, he also states that mind map can be used for any goals, such as mind map for working, mind map for meeting, mind map for planning etc.

The creativity can be seen from how the maker uses their idea to link one key word to another and another key word to others. The link of one sub key word to others is called creativity because the maker tries to use his brain to think deeper about what the relation of his ideas to others. 
The association is the action from the maker to use his imagination to use pictures, colors, images for the representative of his creativity. From all steps mentioned, they will ease the maker to recall his idea through his own mind map. As it is pointed by Buzan (2003, p.97), there are two kinds of creativity; imagination and association. He adds that in order to train creativity, mind map is needed. Imagination and association always present in the process of making a mind map.

The more the learners get used to making the mind map in groups, in pairs or even alone, the more they understand how to build their own memorizing through mind mapping.

\section{Music}

Another way to succeed in learning is through listening to music. Why? The following explanation will discuss the importance of music for learners. Music has become central culture and plays important role to influence people's mind and emotion. Music is also believed to be a favorite choice to accelerate learning (Prashnig, 2007 p.185).

According to Irvin (Prashnig, p. 2007, p.187), he says that music gives great benefit to brain while music used to stimulate the brain to work well. He made a very well known research in 1993 reveal the correlation between listening to classical music and learning. The result explained that the students who listened to Mozart had greater score than those who did not have the music while they were studying.

Researchers say that; however, not all kinds of music suit for stimulating brain. Don Campbell, as mentioned on Hardiwinoto (2003, p.45), states that people must be selective to choose kinds of music that is suitable to enhance the brain's function. Campbell then concludes that sound, song and rhythm physically, emotionally, and spiritually strengthens thinking to make someone more creative. Moreover, Hal A.Lingerman Hardiwonoto (2003, p.50) finds that music gives not only as a cure for treatment but positives effects to baby's brain also. Therefore, then Howard Gardner (Hardiwinoto.2003, p.51-52), multiple intelligences theory founder, underlines music intelligence is one of the seven multiple intelligences models which always exist in somebody's intelligences.

De Porter et al (2000, p.73) refers to what Lozanov found that Baroque composition helps learners to work better and remember more about what they study since music stimulates and strengthens to study consciously or not. This correlates to the right brain function, the right brain as a place for music store which then stimulates the brain to study better. Furthermore, according to Stephanie Merek, a Lozanov teacher, points out that only whole classical composition are now used in Lozanov classes because they reach and synchronize the whole mind and produce the entire dynamics of inner life (Rose, 1997, p.71).

What do the composers think about the use of classical music including baroque composition? De porter et al (2000, p.75-76) explains there are three things to remember for the use of music in learning process such as synchronizing the feeling, increasing learning result, and enhancing creativity. Hence, there are several recommendations stated almost on every book which enhance the creativity of learning for in the class.

The recommended musics are: Mozart Flute Concertos, Relax with the Classics: Andante and Pastorale, Six Duets for Two Flutesz, Cannon in D by Pachebel, and the Instruments of Classical Music (volume one).

Music for cheer uses: TV's Greatest Hits Series and For Our Children by Disney. Meanwhile, The recommended musics for break uses are: soundtracks movies, oldies hits, contemporary jazz, and ethnic music. Music for relax uses: Windham Hill Records: A Winter's Soltice, Out of Silence by Yanni, Deep Breakfast by Ray Lynch. 
Types of music above are recommended to playing during the whole activities. However, there should be underlined what condition and when the right time the music can be played on the class to assist the teacher to deliver the materials.

\section{DISCUSSION}

\section{Teaching Procedure}

The process of teaching and learning applying memory enhancement seems different from traditional teaching and learning than the formal process conducted at schools. This can be observed from the steps of teaching and learning in the classroom which took the steps from the collaboration of multiple intelligent theories. Here are the steps of teaching procedures that could be applied classes compared with traditional teaching in formal schools (Tabel 1):

Tabel 1

Comparisons of Memory Enhancement Teaching Procedure and Traditional Teaching Procedure

\begin{tabular}{|c|c|c|c|}
\hline \multicolumn{2}{|c|}{$\begin{array}{l}\text { Memory Enhancement } \\
\text { Teaching Procedure }\end{array}$} & \multicolumn{2}{|c|}{$\begin{array}{l}\text { Traditional } \\
\text { Teaching Procedure }\end{array}$} \\
\hline (1) & Opening (with giving mind map) & $(1)$ & Opening (without giving mind map) \\
\hline (2) & $\begin{array}{l}\text { Delivering materials (with giving mnemonics } \\
\text { forms) }\end{array}$ & $(2)$ & $\begin{array}{l}\text { Delivering materials (without giving mnemonics } \\
\text { forms) }\end{array}$ \\
\hline (3) & $\begin{array}{l}\text { Having a Break (having relaxation, listening to } \\
\text { music and listening to motivation's audio) }\end{array}$ & (3) & $\begin{array}{l}\text { - (no breaking time for relaxation, listening to } \\
\text { music and listening to motivation’s audio) }\end{array}$ \\
\hline (4) & Drilling (practicing the mnemonics technique) & (4) & Drilling(practicing the mnemonics technique) \\
\hline (5) & Closing (Repeating the mnemonics forms) & $(5)$ & Closing (Repeating the mnemonics forms) \\
\hline
\end{tabular}

These five phases of teaching procedure are ruled for teaching grammar done in 60 minutes from the opening until the closing. Here are the teaching procedures using memory enhancement tools.

\section{Opening with Mind Map}

The first step to start teaching is giving mind map to the learners in the class. This activity is done by the teacher by drawing a simple mind map in front of the class ten minutes before the students enter the class. When the learners get into the class, the teacher can explain in short about what topic will be discuss then. The teacher explains the topic by showing the mind map and makes some interaction with the learners by giving short questions relating to the materials will be given that day.

This first procedure reveals that mind map will lead the learners' mind into the core of grammar which then is continued the materials delivery of memory technique presentation. Therefore along with Tony Buzan' statement that mind maps are used to generate, visualize, structure, and classify ideas, and as an aid in study, organization, problem solving, decision making, and writing (2007).

\section{Delivering Materials by Giving Memory Technique}

The usage of the memory technique or mnemonic reveals that learning Grammar is not a must thing to do for teachers and learners to study the grammatical patterns as key points to answer grammar items in a test. If learners memorize bunches of unorganized vocabulary, the learners tend to get difficulties to answer a certain grammar item because they do not know what key words to 
underline from the items. The results will be different in case of memorizing vocabulary with mnemonic in teaching English grammar.

The role of memory technique is very important to emphasize since it will help the learners to recognize the right answer from certain key words given in the items. However, all efforts to memorize the list of mnemonics need to practice many times. Practicing is a way to train the information that the learners acquire. The more the learners practice the information, the more the information will stay longer in the memory.

As mnemonic involves imagination and creativity, the visual learners will receive the topic given easily and will apply it in the test. As the basic characteristic of visual learners loves to make imagination, see something beautiful in colors, and pictures. Mnemonic has one of the characteristics. The mnemonic is associated in someone imagination by linking words into something that the learners understand and imagination. All memory techniques are presented in words which are funny, imaginative, and meaningful.

\section{Having a Break Time}

This is the time for learners to have a break. It takes about five minutes to relaxation or out of the activity of learning the lesson. The learners stop doing all activities of learning such as noting, reading, discussing and asking questions from the materials given. It is the time of the teacher to lead the learners to have in a relax situation, the teacher may ask them to have a little brain gym, listening to favorite songs, and give motivational words.

Buzan (1984) and Rose (1995) suggest that the time break is essential for learners to relax from learning. They say that time break can be done after 30 minutes of learning. The function is to complete the learning process, to incubate the information that the learners receive during the period and to keep the learners concentration keep high. The more time break given the better the concentration can be controlled.

\section{Drilling (Practicing the Mnemonic)}

Having learned the mnemonic given, the learners can apply what it in drilling session. They can practice and it by practicing mnemonic with various items offered and the teacher leads them to practice. Drilling and rehearsing are very important to do after receiving new mnemonic. Indeed, Lorayne (1995, p. 20) adds that memorizing should be practiced repeatedly because memory is habit. Drilling the mnemonic also needs the awareness of the learners to pay attention to the key words showed from the items. Here is the example of the drilling session, Item number eight on topic of Gerund (Foster. 2008).

"Do you like Rendra?"

"Yes, I’m looking forward ... his play tomorrow."
A. seeing
B. to be seeing
C. to see
D. to seeing
E. see

The topic of item above is Gerund, the learners have to understand what the basic concept of Gerund is when they understand about the basic concept of gerund from the explanation before, and then they have to identify the key word from the item above. The teacher reads item aloud in front of the class, and then he gives the learners the key words from the item. 
The key word is looking forward. Having recognized the key words, they should recall their memory to the mnemonic that they have learned before. The mnemonic is O, Be OLACCU to + Ving. It means that all list of the mnemonic must be followed by to and then the following verb must be in ing form. The mnemonic stands for:

Object to

Be Opposed to

Look Forward to

Be Accustomed to + Ving

Confessed to

Be/Get Used to

From the list of mnemonic above, one of the words is Look forward to so the learners then may choose one of the multiple choices to find out which one of the choices is in ing form. Therefore the right answer is (D) to seeing.

The teacher keeps the drilling session by reading the items and asks the learners of what the key words are, what mnemonic matches with, and what the answer suit for the items presented until the class is over.

\section{Closing}

The teacher closes the learning session by asking about what mnemonics that the learners study from the topic that day. This closing time is possible to use for repeating the mnemonics given to the learners randomly.

\section{Implications}

The implications of the teacher factor in teaching using memory techniques or mnemonics are many. The teacher should learn the way of forming mind map and mnemonic for every material or topic that will be delivered in front of classroom. He should not be satisfied alone with the training he received in his institution.

He should explore more and then train the learners to make their own mind map and mnemonics based on their creativity. The teacher should also actively search for the right music to play in the class. He should take time to synchronize the music through the learning process. Thus, teacher is the real model that can lead learners to success (Alabi, 2008).

\section{CONCLUSION}

When an institution decides the age, the level, the materials, and the needs of the learners' goal to learn grammar for test, it must consider the approaches and the techniques given in the classroom. Memory technique or mnemonic has been applied for many researches and they observe that this technique is more effective than the traditional ones. I propose that this technique could be used in grammar classroom; however, it will be more effective if the additional tools such as mind map, music, breaking time are included in the process of transferring. In brief, all process of the teaching procedure must be applied in one package. Thus, through these efforts, the results of enhancing memory will be easily reached. 


\section{REFERENCES}

Alabi, Amos Oyetunde. (2008). The Teacher as a Resource in the Planning and Implementation of Primary English Classes. Pakistan Journal of Sciences, 5 (8), 841-844.

Atkinson, R.C. (1975). Mnemotechnics in Second Language Learning. American Psychologist, 30, 821. 828.

Buzan, Tony. (1984). Use Your Head. London: Guild Publishing.

Buzan, Tony. (1986). Use Your Memory. London: Guild Publishing.

Buzan, Tony. (2003). Head Strong: Memperkuat Hubungan Otak dan Tubuh untuk Mendapatkan Fisik dan Mental yang Fit, (cetakan kedua). Jakarta: Gramedia Pustaka Utama.

Buzan, Tony. (2007). Buku Pintar Mind Map, (cetakan keempat). Jakarta. Gramedia Pustaka Utama.

De Porter, Bobby. (2000). Quantum Teaching. Bandung: Kaifa.

Foster, Bob \& Mulyana, Ade. (2008). Kumpulan Soal dan Pembahasan Bahasa Inggris SNMPTN 2001 - 2008, UM-UGM 2003-2008, dan UMB 2008 Soal dan Pembahasan. Bandung: Ganesha Operation.

Gannerud, Eva \& Ronnerman, Karin. (2005). Studying Teachers’ Work through Mind-Maps. New Zealand Journal of Teachers' Work, 2(2), 76-82.

Hardiwinoto \& Setiabudi, Tony. (2003). Anak Unggul Berotak Prima. Jakarta: Gramedia Pustaka Utama.

Joyce, B. \& Weil, M. (2000). Models of Teaching, ( $6^{\text {th }}$ ed.). Boston: Allyn and Bacon.

Lorayne, H., \& Lucas, J. (1974). The Memory Book. New York: Stein and Day

Lorayne, Harry. (1995). How to Develop a Super Power Memory. Florida: Frederick Fell.

Meier, P.S. (2007). Mind-Mapping, 52, 1-4. Accessed from http://www.soc.surrey.ac.uk/sru/SocialResearchUpdate

Prashnig, Barbara. (2007). The Power of Learning Styles. Bandung: Kaifa.

Pressley, M., \& Dennis-Rounds, J. (1980). Transfer of a Mnemonic Keyword Strategy at Two Age Levels. Journal of Educational Psychology, 72(4), 575-582.

Richmond, Aaron S., Cummings, Rhoda, \& Klapp, Michael. (2008). Transfer of the Method of Loci, Pegword, and Keyword Mnemonics in the Eight Grade Classroom. Researcher, 21(2).

Rose, Colin. (1995). Accelerated Learning: Action Guide. Iilinois: Nightingale Conant.

Rose, Colin. (1997). Accelerated Learning: How Memory's Secrets Unlocked the Way to Relaxed, Easy Learning. Great Missenden, Bucks: Accelerated Learning Systems. 